\title{
EVALUASI PELAKSANAAN PEMUNGUTAN, PENYETORAN DAN PELAPORAN PAJAK PENGHASILAN (PPH) PASAL 22 WAJIB PUNGUT BUMN PADA PT. TELEKOMUNIKASI INDONESIA CABANG MANADO
}

\author{
Romullo Matthew Salaki ${ }^{1}$, Harijanto Sabijono ${ }^{2}$ \\ ${ }^{1,2}$ Jurusan Akuntansi, Fakultas Ekonomi dan Bisnis, Universitas Sam Ratulangi, Jl. Kampus Bahu, Manado \\ Indonesia, 95115 \\ E-mail: salakimatthew@gmail.com
}

\begin{abstract}
Taxation is the sector that produces the most in an effort to increase state revenue. Through taxation, Indonesia is better able to submit requests for national development and other sector allocations. The appropriate method used in the special tax sector is a tax collection system that memebri for taxpayers, collect, deposit, and report the tax payable to the state treasury. The purpose of this study was to study the Evaluation of the Implementation of Collection, Depositing and Reporting of Income Tax Article 22 Obligatory SOE Levies at PT. Telekomunikasi Indonesia, Manado Branch. This research uses a descriptive qualitative research system. The results of research at PT. Telekomunikasi Indonesia, Manado Branch, can be accessed by collecting, depositing, and reporting income tax PP 22 mandatory SOE levies using a self-assessment system that is a tax collection system that authorizes taxpayers in the regulation of applicable tax invitations.
\end{abstract}

Keywords: collection; deposit; reporting; income tax article 22

\section{PENDAHULUAN}

Negara Kesatuan Republik Indonesia adalah negara yang setiap tahun berusaha untuk meningkatkan pendapatan negara yang berasal dari berbagai sektor guna meningkatkan pembangunan di segala bidang. Perpajakan merupakan sektor pendapatan utama dalam upaya peningkatan pendapatan negara. Penerimaan pajak dapat menjadi sumber dana pembangunan nasional. Pembangunan Nasional yang membutuhkan dana yang besar memerlukan usaha peningkatan di sektor pajak yang bertujuan untuk membiayai negara. Cara yang tepat digunakan pada sektor pajak khususnya adalah sistem pemungutan pajak yang memberikan pada Wajib Pajak untuk menghitung, memungut, menyetor, dan melaporkan pajak terutangnya pada kas negara. Proses menghitung, memungut, menyetor, dan melaporkan pajak terutang dibutuhkan beberapa contoh penerapannya, salah satu contoh yang digunakan adalah PT. Telekomnikasi Indonesia Cabang Manado yang merupakan subjek pajak dalam Negeri yang ditunjuk oleh kantor Pelayanan Pajak (KPP) sebagai pemungut pajak dalam rangkaian transaksinya dengan beberapa instansi ataupun rekanan. Penunjukkan tersebut telah berdasarkan hak yang diberikan oleh Kantor Pelayanan Pajak (KPP) kepada PT. Telekomunikasi Indonesia Cabang Manado yang merupakan Badan Usaha Milik Negara (BUMN).

Pemerintah menggalakkan sumber penerimaan yang paling besar yaitu pajak, penting adanya partisipasi masyarakat Indonesia untuk membayar pajak, untuk menjadikan pajak sebagai sumber pembiayaan pembangunan yang utama bukan hal yang mudah, banyak kendala-kendala yang dihadapi baik yang timbul dari masyarakat sebagai wajib pajak maupun dari pihak aparat pajak serta peraturan perundang-undangan. Jenis kegiatan yang dilakukan oleh masyarakat Indonesia selaku warga negara Indonesia dalam menggerakan roda perekonomian sekaligus sebagai objek pajak merupakan salah satu faktor yang menentukan jenis pajak serta beberapa besarnya pajak yang dikenakan. Jenis Pajak yang 
memiliki kontribusi cukup besar terhadap penerimaan pajak adalah Pajak Penghasilan $(\mathrm{PPh})$ yang diperoleh dari penghasilan perseorangan ataupun entitas.

Penghasilan merupakan setiap tambahan kemampuan ekonomis yang diterima atau diperoleh Wajib Pajak, baik yang berasal dari Indonesia maupun yang dari luar Indonesia, yang dapat dipakai untuk konsumsi atau untuk menambah kekayaan Wajib Pajak yang bersangkutan, dengan nama dan dalam bentuk apa pun berdasarkan (Undang-Undang No. 36 Tahun 2008 tentang Pajak Penghasilan). Menurut Marina et al. (2013), pajak merupakan iuran yang dipungut oleh negara baik oleh pemerintah pusat maupun pemerintah daerah berdasarkan undang-undang serta aturan pelaksanaan pemungutan pajak yang mengisyaratkan adanya alih dana dari sektor swasta wajib pajak yang membayar pajak ke sektor Negara Pemungutan Pajak Pemerintah dan diperuntukan bagi keperluan pembiayaan umum pemerintah, baik rutin maupun pembangunan.

\section{TINJAUAN PUSTAKA}

Menurut Andriani (2012), pajak adalah iuran kepada negara (yang dipaksakan) yang terutang oleh yang wajib membayarnya menurut peraturan-peraturan, dengan tidak mendapat prestasi kembali, yang langsung dapat ditunjuk, dan yang gunanya adalah untuk membiayai pengeluaran-pengeluaran umum yang berhubungan dengan tugas Negara yang menyelenggarakan pemerintahan. Menurut Soemitro dalam Mardiasmo (2011), pajak adalah iuran rakyat kepada kas Negara berdasarkan Undang-Undang (yang dapat dipaksakan) dengan tidak mendapat jasa timbal balik (kontraprestasi) yang langsung dapat ditunjukkan, dan yang digunakan untuk membayar pengeluaran umum. Sedangkan menurut Resmi (2014), pajak adalah suatu kewajiban menyerahkan sebagian dari kekayaan ke kas negara yang disebabkan suatu keadaan, kejadian, dan perbuatan yang memberikan kedudukan tertentu, tetapi bukan sebagai hukuman, menurut peraturan yang ditetapkan pemerintah serta dapat dipaksakan, tetapi tidak ada jasa timbal balik dari Negara secara langsung, untuk memelihara kesejahteraan umum.

Terdapat dua fungsi pajak menurut Resmi (2014) yaitu: (a) fungsi budgetair (sumber keuangan negara) atau sumber penerimaan pemerintah untuk membiayai pengeluaran baik rutin maupun pembangunan; dan (b) fungsi regulerend (pengatur) atau alat untuk mengatur atau melaksakan kebijakan pemerintah dalam bidang sosial dan ekonomi, serta mencapai tujuan-tujuan tertentu di luar bidang keuangan. Menurut Resmi (2014), terdapat berbagai jenis pajak, yang dapat dikelompokan menjadi tiga, yaitu pengelompokan menurut golongan menurut sifat, dan menurut lembaga pemungutnya.

Menurut Mardiasmo (2011), terdapat 4 (empat) tarif pajak, yaitu tarif sebanding atau proposional, tarif tetap, tarif progesif, dan tarif degresif. Menurut Resmi (2014), dalam memungut pajak dikenal 3 sistem pemungutan pajak yaitu official assessment system, self assessment system, dan withholding system. Menurut Rahayu (2010), pajak penghasilan adalah pajak yang terhutang sehubungan dengan pekerjaan, jasa, dan kegiatan yang wajib dipotong dan disetorkan oleh pembeli kerja. Jadi Pajak Penghasilan merupakan pajak atas penghasilan berupa gaji, upah, Honorurium, tunjangan dan pembayaran lain sengan nama dalam bentuk apapun sehubungan dengan pekerjaan atau jabatan, jasa dan kegiatan yang dilakukan oleh orang pribadi subyek pajak dalam negeri.

Menurut Tjahyono dan Mahagiyani (2001), Pajak Penghasilan Pasal 22 merupakan pajak penghasilan yang dipungut oleh Bendaharawan Pemerintah dan Lembaga - lembaga Negara lainnya berkenan dengan pembayaran atas penyerahan barang dan badan badan tertentu baik badan pemerintah maupun swasta berkenaan dengan kegiatan di bidang import atau kegiatan usaha di bidang lainnya.

Menurut Risman (2013), pemungutan Pajak Penghasilan 22 wajib disetor oleh bendahara ke kas melalui kantor pos, bank devisa, atau bank yang ditunjuk oleh Menteri 
Keuangan, dengan menggunakan surat pajak yang telah di isi atas nama rekanan serta di tandatangani oleh pemungutannya dengan menggunakan Surat Pemberitahuan Masa ke Kantor Pelayanan Pajak.

Sondakh (2013) menunjukkan bahwa hasil perhitungan dan pelaporan Pajak Penghasilan Pasal 22 sudah sesuai dengan aturan perundang undangan yang berlaku yaitu PMK No.154/PMK.03/2010. Hasil penelitian Tarigan et al. (2015) menunjukkan bahwa penghitungan dan pelaporan Pajak Penghasilan Pasal 22 atas pengadaan barang pada Kantor Badan Perencanaan Pembangunan Penanaman Modal dan Statistik Daerah Kabupaten Bolaang Mongondow belum mengikuti beberapa peraturan yang berlaku saat ini mengenai perhitungan dan pelaporan Pajak Penghasilan Pasal 22 atas pengadaan barang.

Menurut Sorongan (2014), pemungutan PPh Pasal 22 terjadi peningkatan dari tahun 2012 ke tahun 2013 akan tetapi PPh Pasal 22 tidak dilaporkan dalam SPT Masa melainkan dilaporkan bersamaan dengan SPT Tahunan. Irwanti dan de Poere (2015) menemukan bahwa penerapan dan pelaporan pasal 22 sebagai pemungut pada Dinas Pengelolaan Keuangan dan Barang Daerah Kabupaten Bogor telah sesuai peraturan. Menurut Hidayah dan Listiono (2015), perhitungan PPN dan PPh Pasal 22 atas pengadaan alat kesehatan laboraturium pada Dinas Kesehatan Provinsi Jawa Tengah sudah sesuai dengan Undang-Undang yang berlaku.

Hasil penelitian Kussoy et al. (2014) menunjukkan bahwa pelaporan PPh pasal 22 pada PT. PERTAMINA Manado telah sesuai dengan ketentuan perpajakan yang berlaku. Hasil penelitian Azis dan Budiarso (2016) menunjukkan bahwa pemungutan dan perhitungan serta pelaporan pajak PPh Pasal 22 atas kegiatan impor barang pada Kantor Pelayanan dan Pengawasan Bea dan Cukai Kota Manado telah sesuai dengan PMK No. 175/PMK.011/2011.

\section{METODE PENELITIAN}

Jenis penelitian yang digunakan adalah penelitian dekripstif-kualitatif. Penelitian kualitatif adalah penelitian yang bermaksud untuk memahami fenomena tentang apa yang dialami oleh subjek penelitian misalnya perilaku, persepsi, motivasi, tindakan dan lain-lain (Moleong, 2007:6). Prosedur pengumpulan data dalam penelitian ini dilakukan melalui tahap-tahap yaitu wawancara, dokumentasi, dan tinjauan pustaka.

\section{HASIL PENELITIAN DAN PEMBAHASAN}

\subsection{Hasil penelitian}

PT. Telekomunikasi Indonesia, (Telkom) adalah BUMN yang bergerak di bidang jasa layanan Telekomunikasi dan jaringan di wilayah Indonesia. Saat ini sahamnya dimiliki oleh Pemerintah Indonesia (53,6\%), dan 46,4\% dimiliki oleh Publik, Bank of New York, dan Investor dalam Negeri. Telkom mempunyai 13 anak perusahaan. Telkom telah melayani lebih dari 151,9 juta pelanggan yang terdiri dari seluler (Telkomsel) lebih dari 125 juta dan pelanggan tetap 25,8 juta.

Perusahaan ini menyediakan berbagai layanan komunikasi lainnya termasuk interkoneksi jaringan telepon, multimedia, data dan layanan terkait komunikasi internet, sewa transponder satelit, sirkit langganan, televisi berbayar dan layanan VIP. Perusahaan yang memiliki visi menjadi perusahaan yang unggul dalam penyelenggaraanTelecommunication, Information, Media, Edutainment dan Services ("TIMES") di kawasan regional ini telah mendominasi lebih dari 60 persen pangsa pasar Broadband Indonesia.

\subsection{Pembahasan}

Manajemen secara periodik mengevaluasi perlakuan pajak yang diterapkan dalam Surat Pemberitahuan Tahunan (SPT) sehubungan dengan situasi dimana aturan pajak yang berlaku membutuhkan interpretasi. Jika perlu, manajemen menentukan provisi berdasarkan jumlah yang diperkirakan akan dibayar kepada otoritas pajak. Berdasarkan hasil wawancara dan observasi di PT. Telekomunikasi Indonesia Cabang Manado dapat diketahui bahwa 
dalam Pemungutan, Penyetoran dan Pelaporan Pajak Penghasilan PPh Pasal 22 wajib pungut BUMN menggunakan Self Assessment System yaitu Sistem Pemungutan Pajak yang memberi wewenang Wajib Pajak dalam menentukan sendiri jumlah pajak yang terutang setiap tahunnya sesuai dengan peraturan perundang - undangan perpajakan yang berlaku. sistem ini, inisiatif sera kegiatan menghitung dan memungut pajak sepenuhnya berada ditangan wajib pajak. Wajib Pajak dianggap mampu menghitung pajak, mampu memahami Undang-Undang Perpajakan yang sedang berlaku, dan mempunyai kejujuran yang tinggi, serta meyadari akan arti pentingnya membayar pajak.

Pemungutan Pajak Penghasilan PPh 22 di PT. Telekomunikasi Indonesia Cabang Manado sesuai dengan Peraturan Menteri Keuangan Nomor 107/PMK.010/2015, dimana penyetorannya dilakukan oleh importir yang bersangkutan atau Direktorat Jenderal Bea Cukai ke kas Negara melalui Bank Persepsi yang ditunjuk oleh Menteri Keuangan selaku Bendahara Umum Negara (BUN). Pelaporan PT. Telekomunikasi Indonesia Cabang Manado menguraikan semua data terkait laporan keuangan khususnya pada poin perpajakan pada laporan konsolidasi per triwulan yang bisa di akses di Bursa Efek Indonesia. Adapun kendala-kendala yang dihadapi dalam pemungutan, penyetoran dan pelaporan hanya terkait dengan mekanismenya saja.

\section{KESIMPULAN DAN SARAN}

\subsection{Kesimpulan}

Berdasarkan hasil penelitian di PT. Telekomunikasi Indonesia Cabang Manado dapat diketahui bahwa dalam pemungutan, pelaporan dan penyetoran Pajak Penghasilan PPh Pasal 22 wajib pungut BUMN menggunakan Self Assessment System yaitu Sistem pemungutan pajak yang memberi wewenang Wajib Pajak dalam menentukan sendiri jumlah pajak yang terutang setiap tahunnya sesui dengan peraturan perundang-undangan perpajakan yang berlaku. Pemungutan, penyetoran, dan pelaporan Pajak Penghasilan PPh pasal 22 wajib pungut BUMN pada PT. Telekomunikasi Indonesia Cabang Manado sudah sesuai dengan Peraturan Menteri Keuangan Nomor 107/PMK.010/2015. Adapun kendala-kendala yang dihadapi hanya terkait dengan masalah mekanisme pemungutan.

\subsection{Saran}

Saran yang dapat diberikan untuk PT. Telekomunikasi Indonesia Cabang Manado adalah agar tetap menjaga kepatuhan dalam melaksanakan kewajiban perpajakan sesuai dengan peraturan yang berlaku untuk menghindari adanya sanksi - sanksi yang ada dan dapat mengatasi semua kendala sistem makanisme yang terjadi dalam proses pemungutan, pelaporan, dan penyetoran Pajak Penghasilan Pasal 22 pada PT. Telekomunikasi Indonesia Cabang Manado.

\section{DAFTAR PUSTAKA}

Andriani, P., J., A. (2012). Akuntansi Pajak. Jakarta: Salemba Empat.

Azis, A. R., A., \& Budiarso, N. (2016). Analisis pemungutan dan pelaporan pajak PPh pasal 22 atas kegiatan impor barang pada Kantor Pelayanan Dan Pengawasan Bea dan Cukai Kota Manado. Jurnal EMBA: Jurnal Riset Ekonomi, Manajemen, Bisnis dan Akuntansi, $4(1)$,

753-762. https://ejournal.unsrat.ac.id/index.php/emba/article/view/11781

Hidayah, I., \& Listiono, A. (2015). Perhitungan PPN dan PPh Pasal 22 atas pengadaan alat kesehatan/bahan peralatan kesehatan laboratorium/radiologi pada Dinas Kesehatan 
Provinsi Jawa Tengah tahun 2013. Jurnal Akuntansi dan Perbankan Indonesia, 23(1), 50-66. https://jurnal.polines.ac.id/index.php/jabpi/article/view/599

Irwanti, I., \& de Poere, D. B. (2015). Penerapan perhitungan dan pelaporan PPh Pasal 22 sebagai pemungut pada Dinas Pengelolaan Keuangan Dan Barang Daerah Kabupaten Bogor.

https://www.researchgate.net/profile/Daniel_De_Poere/publication/336373750_PENE RAPAN_PERHITUNGAN_DAN_PELAPORAN_PPH_PASAL_22_SEBAGAI_PE MUNGUT_PADA_DINAS_PENGELOLAAN_KEUANGAN_DAN_BARANG_DA ERAH_KABUPATEN_BOGOR/links/5d9ebdbb92851cce3c91182e/PENERAPANPERHITUNGAN-DAN-PELAPORAN-PPH-PASAL-22-SEBAGAI-PEMUNGUTPADA-DINAS-PENGELOLAAN-KEUANGAN-DAN-BARANG-DAERAHKABUPATEN-BOGOR.pdf.

Kussoy, E. B., Saerang, D., P., E., \& Pontoh, W. (2014). Evaluasi perhitungan dan pelaporan pajak PPh 22 atas penebusan bahan bakar minyak di PT. Pertamina Manado. Going Concern: Jurnal Riset Akuntansi, $\quad 9(1), \quad 69-78$. https://doi.org/10.32400/gc.9.1.25195.2014.

Tjahyono, A., \& Mahagiyani. (2001). Perpajakan Indonesia: Pendekatan soal dan jawab kasus. Jakarta: PT. Raja Grafindo Persada.

Mardiasmo. (2011). Perpajakan. Edisi Revisi. Yogyakarta: Penerbit Andi.

Marina, Kurniawan, R., \& Tarigan, L. (2013). Evaluasi penerapan PPh Pasal 23 pada PT. BIN (Persero) di tahun 2012. Buletin Ekonomi, 17(2), 41-47. http://ejournal.uki.ac.id/index.php/beuki/article/view/291

Sondakh, M. R. (2013). Evaluasi perhitungan dan pelaporan pajak PPh 22 atas import barang. Jurnal EMBA: Jurnal Riset Ekonomi, Manajemen, Bisnis dan Akuntansi, 1(3) 419426. https://ejournal.unsrat.ac.id/index.php/emba/article/view/1841

Moleong, L. (2007). Metode penelitian kualitatif, Edisi Revisi. Bandung: PT. Remaja Rosdakarya.

Risman, M. A. (2013). Perpajakan bagi Bendahara Pemerintah. Bandung: Penerbit Fokusmedia.

Rahayu, S. K. (2010). Perpajakan Indonesia: Konsep dan aspek formal. Yogyakarta: Graha Ilmu.

Resmi, S. (2014). Perpajakan: Teori dan kasus, Buku 1 Edisi 8. Jakarta: Salemba Empat.

Sorongan, C., T. (2014). Perhitungan dan pelaporan Pajak Penghasilan Pasal 22 atas pengadaan barang pada Kantor Pelayanan Perbendaharaan Negara Kota Bitung. Jurnal EMBA: Jurnal Riset Ekonomi, Manajemen, Bisnis dan Akuntansi, 2(1), 704714. https://ejournal.unsrat.ac.id/index.php/emba/article/view/4385

Tarigan, M. E. R., Morasa, J., \& Elim, I. (2015). Perhitungan dan pelaporan Pajak Penghasilan Pasal 22 atas pengadaan barang pada Kantor Badan Perencanaan Pembangunan Penanaman Modal dan Statistik Daerah Kabupaten Bolaang Mongondow. Jurnal Berkala Ilmiah Efisiensi, 15(3), 152-167. https://ejournal.unsrat.ac.id/index.php/jbie/article/view/9357 